МРНТИ 16.21.55

https://doi.org/10.51889/2021-1.1728-7804.13

\author{
Namazova $F^{l}$ \\ ${ }^{1}$ Mingachevir State University, \\ Azerbaijan, Baku
}

\title{
CHARACTERISTICS OF DRAMA GENRE AND DRAMA LANGUAGE
}

\begin{abstract}
Addressing the specific problems of dramatic creativity, we must first determine the basic meaning of the term "drama". As we know, the word "drama" has different meanings. We also call a certain range of real events, for example, the drama of life, one of the genres of the dramatic type of literature (the noble drama of the eighteenth century) and the dramatic theater, which is the leading type of performing arts. Dramatic works are fundamentally different from other genres. As early as the 19th century, the great thinker MFAkhundov distinguished the genre of drama he brought to our literature from other genres in terms of language and style. Both in his article "Fihristi-kitab" and in his "critiKue" of Mirza Malkum khan's plays, he clearly showed the "conditions of dramatic art".
\end{abstract}

Key words: drama, genre, language, character, creativity, M.F Akhundov, I.Afandiyev

$$
\begin{gathered}
\text { Намазова Ф.К. }{ }^{l} \\
{ }^{I} \text { Мингечевирский Мемлекеттік } \text { Университет, } \\
\text { Азербайджан, Баку }
\end{gathered}
$$

\section{ДРАМА ЖАНРЫ МЕН ДРАМА ТІЛІНІН СИПАТТАРЫ}

\section{Аңдатпа}

Драмалық шығармашылықтың нақты мәселелерін шеше отырып, алдымен “драма” терминінің негізгі мағынасын анықтауымыз керек. Біздің білетініміздей, “драма” сөзі әр түрлі мағынаға ие. Біз белгілі бір нақты оқиғалар диапазонын, мысалы, өмір драмасын, әдебиеттің драмалық типінің (XVIII ғасырдың асыл драмасы) жанрларының бірі және орындаушылық өнердің жетекші түрі болып табылатын драмалық театр деп атаймыз. . Драмалық шығармалар басқа жанрлардан түбегейлі ерекшеленеді. XIX ғасырдың өзінде-ақ ұлы ойшыл М.Ф.Ахундов әдебиетімізге әкелген драматургия жанрын басқа жанрлардан тілі мен стилі бойынша ажыратқан. Ол өзінің “Фихристи-кітап” мақаласында да, Мырза Малқұм ханның пьесаларын “сынға алуда” да “драмалық өнердің шарттарын”.

Түйін сөздер: драма, жанр, тіл, кейіпкер, отырып, М.Ф. Ахундов, И.Афандиев

$$
\begin{gathered}
\text { Намазова Ф.К. }{ }^{l} \\
{ }^{I} \text { Мингечевирский Государственный Университет, } \\
\text { Азербайджан, Баку }
\end{gathered}
$$

\section{ХАРАКТЕРИСТИКИ ДРАМАТИЧЕСКОГО ЖАНРА И ЯЗЫКА ДРАМЫ}

\section{Аннотация}

Обращаясь к конкретным проблемам драматического творчества, необходимо прежде всего определить основной смысл термина «драма». Как известно, слово «драма» имеет разные значения. Мы также называем определенный круг реальных событий, например, драму жизни, один из жанров драматической литературы (благородная драма XVIII века) и драматический театр, который является ведущим видом исполнительского искусства. Драматические произведения кардинально отличаются от других жанров. Еще в XIX веке великий мыслитель М.Ф.Ахундов отличал принесенный им в нашу литературу драматический жанр от других жанров по языку и стилю. И в статье “Фихристи-китаб”, и в “критике” пьес Мирзы Малкум хана он четко показал «условия драматического искусства».

Ключевые слова: драма, жанр, язык, персонаж, творчества, М. Ф. Ахундов, И. Афандиев

Introduction. Studies in literary theory show that the term "drama" comes from the Greek word for movement, action, and dynamics. Action is one of the main features of a play. Rather, it is based on a visual description of life processes through dialogues throughout the development of the entire plot line [3,114]. In dramatic works, the internal and external types of the dynamics of the development of the movement that manifests the events must be expressed in unity. In this case, the play acKuires an exhaustive model and essence of drama and dynamics. In dramaturgy, the presentation of man as a being is given with greater moral and psychological tension, emotional and dramatic 
anticipation than in prose. This "expectation" is realized through various means of language. In dramas, the writer's intentions and actions - the words and ideas he wants to convey - are reflected in the character, actions, gestures, facial expressions and speech of the characters. As in other literary genres, dramaturgy has always been the most important source of facts that reflect the richness, diversity and regularity of the living vernacular. In such works, the most general, the most individual character of language is "hidden". In the language of drama, words and expressions can gain new meaning and subtlety of meaning, the stylistic color of words and expressions changes. Therefore, one of the most characteristic features of dramas is its language and style. This language and style is the literary language of the period when the drama appeared. MFAkhugdov highly appreciates the art of drama, one of the creative forms that actively influences the morality, desires and ideas of the audience and readers, and wrote: "The purpose of drama is to improve people's morals, to guide readers and listeners" [2, 238]. Indeed, the art of drama teaches self-awareness, hatred of ugliness, and arouses public sympathy as a school of thought. [4, 17].

The events that take place and are written by the playwright with the participation of the heroes, the feelings of inner joy and shock, protest and struggle are important in the work of spiritual education and the formation of an active position of the audience. Dramaturgy is a kind of work of art. Its language can be studied not only in terms of expression, but also as a subject of description. Because "language in itself is an integral part of non-artistic reality, and this reality allows the writer to realize his/her creative elements in one way or another, either directly, or in a complex way, indirectly." [15,8].

Research methods. Various scientific methods were used in writing the research. Dramatic works were researched and analyzed. Methods of analysis, synthesis, induction, deduction, comparative analysis were used during the analysis.

Main material. It is clear that there is "no" author's language in dramaturgy. In stage productions, ideas and thoughts, unlike in other genres, are given only in the language of copies. Here, each image speaks on its own behalf, expresses its attitude to events and stories, to time and people; uses every word freely, according to his will; expresses his worldview, expresses desires and thoughts through words and expressions. Great artists always pay special attention to the individualization and typification of the language and speech. In dramaturgy, words are actions, conflicts. Each lexical unit activates the image, warms the heart, amazes, prepares for the answer to the Kuestion of the future. Therefore, the use of words, dialogue and monologue in a stage production reKuires special skills and talent from the playwright. [14, 28-29].

As a type of fiction, the specifics of dramatic works suggest that the main layers of these means of speech are expressed in language units, the methods of their creation, the organization of the text specific to literary and nonliterary speech.

To clarify the conditions of stage pronunciation in dramaturgy - the attitude of pronunciation of characters and images, on the one hand, to the norms of pronunciation of the national literary language, on the other hand, to socialdialect and territorial-dialect speech styles related to various stage images; Determining the relationship between dialogue speech and literary language norms, as well as identifying and analyzing the tools of social speech characterization, the field of socio-speech characterization and psychology, is important for the study of drama texts. "... dialogue speech is the main part of a work of art in which the character-tarological speech is concentrated ... The substitution of dialogues in plays makes the character's speech more prominent, which makes it possible to compare the speech patterns of different characters, to distinguish them from each other. conditions to differentiate. So, the conditions of dialogue can be considered the most important basis for speech ... the most valuable source for the study of dialogue speech is the dramatic text. [17, 146-156].

In dramatic works, speech is described as a system of combining the parts of a dialogue into a whole artistic structure. Therefore, the study of dramatic language should, first of all, focus on the analysis of artistic traditions expressed in the form of dialogue [21, 160]. It is in this context (dialogue process) that the characteristics of the image can be revealed. One of the main features of dramatic works is that in such works the author does not have a descriptive speech. Since the author is unable to intervene, the development of the events here, the inner world of the copies, their actions and deeds, their mood, identity, situation, and ability are expressed in their own speech.

In dramatic works, more attention is paid to the speech of the characters. Various language tools are used to create colorful, vivid speech and to individualize and typify it.

They have been studying the language of drama in Azerbaijan since the 1940s. In the 1940s, A. Demirchizade wrote a booklet "On the language of MFAkhundov and the language of MFAkhundov" (1941), in which he spoke about the language of drama. The author gave interesting scientific information about the language of MF Akhundov's plays "Haji Gara", «Sərguzəsti-Vəziri-Xani-Lənkəran» ("Adventure-Vaziri-Khani-Lankaran"), "Monsieur Jordan and Dervish Mastali Shah". A. Demirchizadeh used the techniKue of comedy and the language of comedy in MF Akhundov's plays by a number of means - type, situation, character, self-satisfaction - selfishness, stupid type and stupid action; humor and irony, language, replica, readiness, proverbs, idioms; vulgar expressions, curses and swearing; summarized the same expression or words with reference to means such as repetition or lengthy speech [7, 34-40].

Kuite high opinions have been expressed about the language of drama. Russian linguists VV Vinogradov, R.A. Budagov, AI Yefimov, N.M. The views and opinions of Shansky, A. Demirchizade, A. Akhundov, T. Hajiyev, N. Abbasova, M. Adilov, G. Kazimov, M. Mammadov and other Azerbaijani linguists in this field are commendable. Literary critics M.Arif, K.Talibzade, M.Huseyn, B.Nabiyev, M.Mammadov, A.Safiyev, S.Asadullayev, G.Khalilov, I.Rahimli have studied I.Efendiyev's creativity from various aspects in their works and articles. 
It should be noted that Ilyas Efendiyev's dramatic language was not the subject of special research. Only IB Salmanov in his dissertation analyzed the phraseological materials in the dramas of the writer [18]. A.Salahova in her monograph "Creative poetics of Ilyas Efendiyev" spoke about the linguistic and artistic features of his prose works. Articles have been written about the originality of the playwright's literary language and the individuality of his style [20, 281-284].

Ilyas Efendiyev was one of the prominent figures of twentieth-century Azerbaijani literature and one of the most talented artists in the field of prose and drama. His numerous stories, short stories and novels, dramas on historical and modern themes are among the beloved and eagerly read works of our national literature.

Ilyas Efendiyev is a playwright of the stage of social realism. It has already been confirmed that the repertoire of the Azerbaijani theater at this stage consisted only of the rich dramaturgy of the writer. There was a need to comprehensively study the dramatic activity of this great playwright, as well as his language and stylistic features.

Ilyas Efendiyev's work has always resisted ideological influence in the broadest sense of the word. Although this resistance is not directly felt in the first prose works and dramas, it is possible to observe this aspect in the choice of subject, in the deep layers of the characters' thoughts. In this sense, it is interesting to note that as the creative experience grows from work to work, the writer tries not to be confined to the social problem, the tendency to penetrate into the inner worlds of images and expand the scope of artistic interpretation. I. Efendiyev's concept of personality is based on the tendency to understand and explain man as a natural being. It is considered to be the first condition of man's existence as a natural being. In I. Efendiyev's dramaturgy, especially in his lyrical-psychological dramas, the trajectory of the plot is based mainly on the motive of love $[16,6]$.

The transition to the method of lyrical-psychological description is the main aesthetic Kuality of the human factor coming to the fore in I. Afandiyev's drama. The idea and content of his dramas were in three directions: 1) artistic presentation of moral and ethical values; 2) artistic presentation of sociological problems; 3) artistic presentation of history.

In the early days of his work, the author focused on sociological problems, and later on moral values. The approach to this problem can be divided into three groups:

1) The social life of the Azerbaijani society in the dramaturgy of Ilyas Efendiyev

2) Moral and moral problems of Azerbaijan in the dramaturgy of Ilyas Efendiyev

3) Historical personalities and events in Ilyas Efendiyev's dramaturgy

Ilyas Efendiyev began his dramatic career in 1943 with his work "Intizar" written together with the people's writer Mehdi Huseyn. In this work, the means of language and speech characteristic of the period were used. Terminology on the subject of war prevails here. The work contains vocabulary and phraseology that reflect the thoughts and attitudes of the people of the war, the social and spiritual-ethical norms of that time.

The playwright's play "IsıKlı yollar" ("Light Roads") reflects the life and struggle of our oil workers. The conversations and dialogues of the characters of the play - a driller, uncle Baba, a young engineer Gulara, Safargulu, Elmar, Salim, Lala and others, who came to work in the city, are characterized by tense situations.

Rural life is also the main theme of Ilyas Efendiyev's dramas. Dramatic events are taking place in rural areas. Rural life creates wide dramatic scenes in Ilyas Efendiyev's «Bahar suları» ("Spring Waters"). The relationship between Alkhan and Ugur is manifested through various linguistic means. Note the example of the people in Alkhan's speech: "O nephew ... they say that one day the eagles gathered and the old eagle chose a leader for themselves. The old eagle did what they needed to do. He gave her babies warm gazelle blood. He showed the way to the madmen. One day a young eagle, returning from a long journey, said to the old eagle, "Why are you pushing us into this narrow rock? Do you know how many places and majestic rocks there are in the world ?! Then the old eagle sighed and called the birds, saying, "Dear ones, I am old. My eyes do not see well. Choose a leader for yourself. " The birds called out, "We can't live without you." The old eagle said, "No, you are wrong. Look at this young eagle." Now his wings are stronger than mine. His eyes see farther." The birds thought, then sighed and confirmed the old eagle's words. [10, 110-111].

This motif reveals that the playwright skillfully used the wisdom of the people and fully resonated with the content of the work. The idea of the drama "man is responsible to society", "civic duty is to protect the people", "man must know why he lives", "family morality is the key to the morality of society" is united with the language of the work.

The idea of comedy is the contrast between nobility and pure love. The events take place in Kislovodsk. Wealth, not true love, stands in the way of love. Although Valeh loves Dadash Rahimovich's daughter, he cannot meet her Kamala.

Family dramas are given at the level of family life. The dramatic model of works reflecting the theme of family dramas not only shows real life, but also demonstrates the author's style as a materialized form of the idea. The system of relations of the characters participating in the dramatic structure creates the author's interpretation of the reality of the time.

Ilyas Efendiyev's drama "Sən həmisə mənimləsən" ("You are always with me") is an artistic understanding of moral problems. Lyrical-psychological mood is the basis of this play. The endless love of an old man and a young girl is the idea of this drama. Another name for this drama is «Boy çiçəyi» ("Flower of height". Where did the name "Boy çiçəyi " come from, and how does it relate to the events in the work? In his speech during the discussion of the play after its performance in 1964, the author clarified this issue: "A few years ago, I saw a flower in the mountains of Karabakh with a strange smell. When i smelled it, it seemed as if the horizons were expanding infinitely. The blue sky 
turns into a mysterious ocean with no end. The dream, on the other hand, flutters its wings in its depths and acKuires an indescribable beauty. Noble feelings and good wishes arise in heart. However, the scent of that flower had a delicate hardness. I asked the villager next to me the name of the flower. He replied that it was called a "Boy çiçəyi" in some places and a "box flower" in others. The bridesmaids pick the flowers and place them between the wedding dresses. Years pass, the flower withers. But still does not lose its aroma. As if it's just peeled off. " [11, 7 c., 260].

The motives of loneliness are strong in the play. "To be alone here is to be faithful to the flower. This loneliness is, in fact, the greatest spiritual unity "[12,34].

According to Yashar Garayev, this work was a new word in our literary life, a successful event, a lyrical, promising drama, a good initiative and experience in creating a modern psychological theater. [13, 117-118].

The drama "Mənim gunahım" ("My Sin") raises important moral issues, and the ways to solve these problems are articulated. The language of the play is characterized by a high degree of imagery.

Ilyas Efendiyev's dramas "Məhv olmus gundəliklər" ("Destroyed Diaries") (1969), "Unuda bilmirəm” ("I Can't Forget") (1968), "Bizim Kəribə taleyimiz" ("Our Strange Fate") (1988) also highlight the moral norms of society.

The play "Bullur sarayda" ("In the Crystal Palace") (1982) also raises the moral problems of society. This drama is the best example of lyrical-psychological style.

In "Tonha iydo agac1" (The Lonely Sucker Tree) (1990), the issues of social and moral debt are presented in a highly artistic language. The playwright used a symbol here. In the play, the image of a fragrant tree has a symbolic meaning, expresses longing for the homeland. The tree that Karim Bey once planted in his homeland was left alone. The writer shows that the Bolshevik regime destroyed not only the people, but also the trees and gardens. Loneliness is a tragedy not only for people but also for trees. [8, 223].

Despite some imperfections, characters Uncle Elmar and Baba in the drama "IsıKl1 yollar" "Light Roads" convinced him that Ilyas Efendiyev could create expressive, typical characters with the help of concise language.

"Psychologism is a feature of a writer's creativity and talent, its defining Kuality. "Spring Waters" is a sociopsychological drama. In this work, the writer was able to create memorable copies such as Kalmagal Madad, Naringul, Sadaf, Turaj, Balli arvad, Khanmurad, and found meaningful details to individualize each of them.

The author, who mastered the style of folk speech, was able to reveal the inner world of the images of Madal and Naringul in a concise way, relying on the original means in the linguistic characterization.

The full and incomplete title of the same drama is "Sən həmisə mənimləsən" ("You are always with me") or "Boy çiçəyi" (1964). The drama is known by its first name. "Boy çiçəyi" is simply a symbol of the moral meaning and aesthetic idea of the drama. Even when it is dry and humorous, the scent stays on forever, as if it has just been peeled. They never lose their fragrance, they do not lose their charm.

The work was the first example of a lyrical-psychological drama. In the dialogues between Hasanzadeh and Nargila, he really created "narrowness of words, breadth of ideas." Here, each reply, Kuestion and answer indicates the moral convictions, beliefs or doubts of the characters...

"Mənim gunahım" ("My Sin") is a work that shows the growing interest of the playwright in serious social problems, the author's search for a lyrical-psychological, intellectual drama, his thoughts on the relationship of life and personality to society.

The playwright prefers to follow the changes in human psychology in the language of drama. Because psychology changes faster than character, it takes some time for this or that innovation in psychology to take shape [6].

"Məhv olmus gundəliklər" ("Destroyed Diaries") is a drama of characters. Ideas and worldviews collide in the person of people who represent certain life and certain social and moral tendencies.

Many of Ilyas Efendiyev's dramas are historical. Although on a historical topic, these works also raise the problems of our modern life and society. Like the idea and content of his historical dramas, the language and style are beautiful. One such drama is "Mahnı daglarda Kaldı" (The Song remained in the Mountains) (1971). In addition to the ideological and artistic Kualities of this drama, researchers on the language recall an episode: "I remember that in the second half of the 1970s, passengers of the Baku metro both knowing Russian or not knowing, were reading Pravda, Komsomolskaya Pravda and Izvestia newspapers as soon as they got into the wagon. It was as if they were saying, "I am civilized, aristocratic, educated." Once, while watching this scene again, I turned to my student friends: "If I had the opportunity, I would take the people in this wagon directly to Azdrama - Ilyas Efendiyev's play" The song remained in the mountains ", and then I would ask:" Which language is better? Yes, this is a strange episode of our past, but it is an instructive history. With his works, Ilyas Efendiyev was fighting against the hateful intentions of the whole system, which were not visible at first glance and were directed against our language. [19].

Ilyas Efendiyev is such an artist of our people that he did not blindly submit to the Soviet regime, did not fit into the inspired literary stereotypes, frameworks and patterns, but tried to tell the truth using all the opportunities of words and art, to reveal the ugliness of the environment. This aspect is evident in the works of the playwright on both historical and modern topics. [1,8].

The play "Sevgililərin cəhənnəmdə vusalı" "Lovers reunion in Hell" (1989) is the first tragic work of I. Afandiyev. The plagues of the period of repression are depicted in the work in the example of innocent people.

The historical drama "Khurshidbanu Natavan" highlights the background, period and life of the poet Kh. Natavan.

Sheikh Khiyabani (1986) is an interesting example of the historical chronicle genre. In this drama, there are characters standing guard over the mother tongue. For example, in the drama "Sheikh Khiyabani", Haji Farhad both 
helps the revolution with money and regulates the activities of the school, which was opened in the Azerbaijani language. $[9,116]$.

Among the historical dramas that serve the idea of national freedom, the play "Hokmdar və Kız1" ("The Ruler and His Daughter") by Ilyas Efendiyev, a professional dramatist, has a special place. Here the drama of the time, the contradictory clashes surrounding the reality, the complex collisions are reflected in the art.

The drama «Tənha iydə agac1» ("Lonely Sucker Tree") (1991) is dedicated to the life of emigrants, the fate of Azerbaijanis living abroad longing for the homeland and the socio-political issues that give rise to this life. These dramas bring to life the literary language of the period in which they were closed.

"On the whole, Ilyas Efendiyev's dramaturgy has its own creative twists and turns, both on the basis of choosing themes and working on them, and often referring to the motives and images that seem closer and necessary to the writer. That is why sometimes the conflict that begins in one of his plays, the series of ideas put forward in another plays, as if it continues, is completed, and thus there is a completeness and connection between the writer's works in terms of ideas, content and style. [5, 515].

Result. The main direction of research in the research work was the mastery of the literary language of Azerbaijani folk writers, the development of the language and style of the drama genre on the basis of their plays, the peculiarities of this genre were identified. The lexical and semantic richness of Akhundov's and Efendiyev's dramatic language is valuable due to its artistic and characterizing factors. The research revealed the skill of playwrights in the use of words, the meaning of words and expressions used in the speech of images and characters, lexical-grammatical, lexical-semantic groups.

\section{References:}

1. Abbasova SI Efendiyev's dramaturgy and modernity. BDU, 2007.

2. Akhundov M.F. Works. Volume 2, Baku, 1951

3. Aliyev MI Fundamentals of literary theory. Baku, "Science and Education" publishing house, 2009, 480 p.

4. Allahverdiyev MG Theater criticism and modernity. Baku: Maarif, 1990, 192 p.

5. Azerbaijan Soviet literature. Baku: Maarif, 1988, 543 p.

6. "Baku" evening newspaper, June 3, 1967.

7. Demirchizade A. M.F.Akhundov about language and M.F. Akhundov's language. Baku: Azerbaijan IFC publication, 1941, $42 \mathrm{p}$.

8. Efendiyev A. Creativity of Ilyas Efendiyev. Baku: Elm, 2000, 310 p.

9. Efendiyev I. Our strange destiny. Plays, memories, novels. Baku, Yazıçı, 1989, 536 p.

10. Efendiyev I. Selected works. Volume II, Baku: Writer, 1984.

11. Efendiyev I. Selected works, in 7 volumes, I-VII volumes, Baku: Chinar-chap, 2002, 448 p.

12. Garayev Y. Ilyas Efendiyev. Baku, "Knowledge" society, 1987, 50 p.

13. Garayev Y. Our stage and contemporaries. Baku, Azerneshr, 1972, pp.117-118

14. Gurbanov A.M. Linguistic analysis of the literary text. Baku, "Nurlan", 2005

15. Kozhevnikova K. Spontaneous oral speech in epic prose. Prague. Karlov University Press, 1970, p. 8

16. Mammadova MI The problem of the hero in Efendiyev's dramaturgy is in the artistic context of the natural existence of man. "Kredo" newspaper, December 31, 2010, p. 6

17. Mammadova Z. Characteristic speech in the literary text. Baku: Elm, 2008, 188 p.

18. Salmanov I. Linguistic and stylistic features of lyric and psychological dramas in Azerbaijani literature (based on the phraseology of the drama of Ilyas Efendiev). Abstract on sois. Scientist. Art. Cand. philol. sciences, Baku, 1983, $23 p$.

19. Tahirli A. Nasir and lyrics of the playwright. Literary Newspaper, October 3, 2003, № 38 (3372).

20. Telmangizi A. Peculiarities of literary language and stylistic individuality. "World of Culture", VII issue. Baku: Nurlan, 2003, p. 281- 284

21. Vinogradov V.V. About the language of fiction. M., Goslitizdat, 1959, p. 469

МРНТИ 16.21.61

https://doi.org/10.51889/2021-1.1728-7804.14

Нәбиева Г.С., ${ }^{1}$ Ибраева Ж.К. ${ }^{2}$

${ }^{1,2}$ Әл-Фараби атындавы Қазақ ұлттық университеті, Алмать, Қазақстан

\section{СУБОРДИНАТИВТІ БИЛИНГВИЗМ ЖАҒДАЙЫНДАҒЫ ТІЛДІК БӘСЕКЕЛЕСТІК}

\section{Аң̧датnа}

Қостілділік - Қазақстандағы тілдік жағдаяттың негізгі көрсеткіші. Мақалада орыс (бірінші тіл) және қазақ тілдерін (екінші тіл) меңгерген автохтонды этнос өкілдерінің орыс-қазақ қостілділігі қарастырылады. Зерттеудің негізгі нысаны интерференция және ұзақмерзімді тілдік қатынастар салдарынан билингвтер 